\title{
David Oliver: Unproductive activity and NHS consultants
}

\section{David Oliver consultant in geriatrics and acute general medicine}

Berkshire

With constrained public money, a growing focus arises on doctors' key role in reducing variation in processes and outcomes and improving value in healthcare, especially how money is spent and what it delivers in outcomes that matter to patients and system efficiencies.

Earlier this year John Appleby published an analysis in The $B M J$ comparing current and historical productivity of NHS consultants. ${ }^{1}$ The headline figures suggest that today's consultants are less productive than their predecessors in crude terms of "volume of output versus unit of input," with consultant expansion unmatched by the more slowly rising volume of clinical activity. Appleby emphasised the importance of considering "quality adjusted" productivity and the need to differentiate elective, outpatient care from acute, unselected care. He noted that, as care becomes more complex, a crude calculation is unhelpful.

Of course, doctors work in teams and organisations, not as lone practitioners. We depend inherently on the availability of decent IT and records, timely investigations, logistical support, adequately staffed multi-professional teams, capacity (in theatres, intensive care, or clinics), or the ability to get patients flowing through the system when community services aren't resourced or functioning.

Into this analysis, I'd add a few more ingredients. Firstly, the era of senior doctors doing ward rounds only twice a week, or being on call only from home, has gone. We're expected to see patients more frequently, earlier in admission, at weekends, and during evenings. This skews the productivity calculus. It's surely the right thing, but its impact on crude productivity is more marginal.

Secondly, as a King's Fund report on frontline care recently showed, ${ }^{2}$ hospital doctors can spend a lot of time battling the poor logistics I've highlighted. And endemic rota gaps in acute medical specialties don't help.

Thirdly, compared with the start of my consultant career 20 years ago, we're drowning in e-correspondence and paperwork.
Consultants had barely any of this administrative burden when we each had personal medical secretaries and no hospital email.

We're expected to see patients more frequently, at weekends, and during evenings. This skews the productivity calculus

Perhaps more importantly, the exponential growth of time spent on documentation for revalidation, appraisal, external regulatory standards, trainees' e-portfolio assessments, mortality reviews, mandatory training, incident reporting, and investigation is out of hand. Clearly, we shouldn't be complacent about patient safety, educational supervision, or professional development. But does every bit of it really add value or merely detract from face to face patient care?

Maybe productivity isn't all that matters anyway. Staff morale is crucial to clinical quality, recruitment, retention, and organisational performance. ${ }^{3}$ Doctors should be encouraged to do wider work for the NHS, in leadership, policy, education, training, and research. ${ }^{4}$ Senior professionals in key roles are not production line automatons. Discussing them as if they were doesn't help them to help patients.

Competing interests: See www.bmj.com/about-bmj/freelancecontributors/david-oliver.

Provenance and peer review: Commissioned; not externally peer reviewed.

Follow David on Twitter: @mancunianmedic

Appleby J. How productive are NHS consultants?BMJ 2017;356:j1520.

2 Ham C, Berwick D; King's Fund. Organising care at the NHS front line: who is responsible? 3 May 2017. https://www.kingsfund.org.uk/publications/organising-care-nhs-front-line.

3 King's Fund. Leadership and engagement for improvement in the NHS: together we can 2012. https://www.kingsfund.org.uk/sites/files/kf/field/field_publication_file/leadership-forengagement-improvement-nhs-final-review2012.pdf.

4 Oliver D. David Oliver: Don't undervalue non-clinical work. BMJ 2016;354:14656. doi:10. 1136/bmj.i4656 pmid:27565513.

Published by the BMJ Publishing Group Limited. For permission to use (where not already granted under a licence) please go to http://group.bmj.com/group/rights-licensing/ permissions 